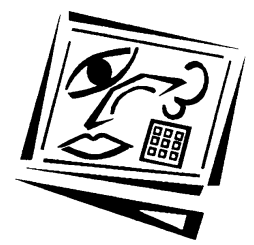

\title{
Perceived convenience in an extended technology acceptance model: Mobile technology and English learning for college students
}

\author{
Chi-Cheng Chang \\ National Taiwan Normal University \\ Chi-Fang Yan \\ National Taichung University of Science and Technology \\ Ju-Shih Tseng \\ National Taiwan Normal University
}

\begin{abstract}
Since convenience is one of the features for mobile learning, does it affect attitude and intention of using mobile technology? The technology acceptance model (TAM), proposed by David (1989), was extended with perceived convenience in the present study. With regard to English language mobile learning, the variables in the extended TAM and its explanatory power were analysed and antecedent factors that affected acceptance of English mobile learning were also examined. Participants were 158 college students from the middle part of Taiwan. After conducting English mobile learning with a PDA, data was collected by questionnaires. The results revealed that: a) perceived convenience, perceived ease of use and perceived usefulness were antecedent factors that affected acceptance of English mobile learning; b) perceived convenience, perceived ease of use and perceived usefulness had a significantly positive effect on attitude toward using; and c) perceived usefulness and attitude toward using had a significantly positive effect on continuance of intention to use. Overall, the extended TAM in the present study was effective at predicting and explaining the acceptance of English mobile learning. In the past, there were few mobile learning related studies examining the relationships between perceived convenience and other variables in the TAM. Therefore, the findings in the present study provide a reference for the future TAM and mobile learning related studies.
\end{abstract}

\section{Introduction}

Mobile learning is a method in which materials are delivered by mobile technology, such as mobile devices and wireless networks (Wang, Wu \& Wang, 2009). Mobile learning contains the features of e-learning and the benefits of mobile technology, which include convenience, immediacy and expediency. Mobile learning is featured by mobility and ubiquity, so it becomes the next milestone of e-learning and educational technology (Peng, Su, Chou \& Tsai, 2009). Mobile devices, such as PDAs ('personal digital asistants') and smart phones (Shih, Chuang \& Hwang, 2010), are portable and can be instant communication tools (Lea \& Callaghan, 2011; Tung, Chang \& Chou, 2008). Wireless networks with functions of immediate connection and transmission (Chinnery, 2006) enable a learner's interactions with learning content, peers and instructors to foster a meaningful knowledge construction and to get the updated 
knowledge (Wang et al., 2009). Mobile technologies can help students interact with one another, collect and analyse data and get instant knowledge and messages in a learning environment.

Learners who study English as a foreign language (EFL) must listen to and practise the language over and over again in order to enhance their learning performance (Thornton \& Houser, 2005). However, class hours are limited, so it is important to develop an efficient tool or method for English learning outside classroom hours. Mobile learning can provide ways for students to learn English at any time and any place. Thornton and Houser (2005) conducted a study about the use of email via mobile phones for learning English vocabulary. Sending English vocabulary to students by mobile phones could efficiently help them to acquire knowledge. Chen and Chung (2008) designed a personalised English vocabulary learning system with PDAs as a supporting tool, based on item response theory and learning memory cycle. The system suggested a learner learns English vocabulary based on his or her English proficiency and memory cycle. The study revealed that an adaptive English vocabulary learning system with a mobile device significantly improved learning performance and motivation. Therefore, mobile learning can efficiently facilitate English learning performance and motivation.

According to a number of studies about information technology and systems (Moon \& Kim, 2001; Roca, Chiu \& Martinez, 2006; Shin, 2007; Yoon \& Kim, 2007), the technology acceptance model (TAM), proposed by Davis (1989), can efficiently predict and explain users' intention and behaviour. Some studies have extended the TAM with external factors to explain and predict users' acceptance of e-learning (Ong \& Lai, 2006; Pituch \& Lee, 2006; Roca et al., 2006; Roca \& Gagné, 2008). Yoon and Kim (2007) extended TAM with perceived convenience, and their results showed that perceived convenience was an external factor that affected users' acceptance of a wireless LAN (local area network). Hossain and Prybutok (2008) also found that perceived convenience affected usage intention with respect to radio frequency identification (RFID). Wireless and RFID are frequently used mobile technologies (Wang, Wu \& Wang, 2009) and therefore perceived convenience could be an important predictor of acceptance of mobile technologies generally. However, so far, there is relatively little research examining the effect of perceived convenience on acceptance of e-learning or mobile learning. Does perceived convenience affect the attitude and intention to use English mobile learning? The issue is worth exploring.

Previous research on English mobile learning (Thornton \& Houser, 2005; Chen \& Chung, 2008) has tended to examine only the usefulness of mobile learning based on knowledge acquisition or learning performance. There are few researches exploring the factors that affect English mobile learning (Lapczynski \& Calloway, 2006; Park, Nam \& Cha, 2011; Tai \& Ting, 2011), so the purpose of the present study was to extend the TAM, proposed by Davis, with another external factor (perceived convenience) which is one of the features of mobile learning. After the students participated in the English mobile learning activities for two weeks, their acceptance toward using the English mobile learning system was investigated by questionnaires. The collected data was analysed by structural equation modeling (SEM) in order to examine: a) relationships between perceived convenience and the variables of the TAM; $b$ ) relationships among variables in the TAM; and c) the predictability of the extended TAM on participants' acceptance of English mobile learning. The study aims to advance understanding of antecedent factors on the acceptance of English mobile learning and relationships among these factors. 


\section{Literature review}

\section{Technology acceptance model (TAM)}

TAM was proposed by Davis based on the theory of reasoned action and aimed to develop a model for explaining and predicting users' acceptance of a certain information system (Davis, Baagozzi \& Warshaw, 1989). From the perspective of TAM, perceived ease of use and perceived usefulness are assumed to be related to the acceptance of a computer or technology system. Perceived usefulness is a belief that a user anticipates that work efficiency can be enhanced by a particular application system; whereas perceived ease of use is a belief that a user expects to not put much effort into making use of a particular system. TAM assumed that: a) the actual use of the computer system is determined by a users' behavioural intention to use; b) users' behavioural intention to use is determined by attitude toward using, and perceived usefulness; c) users' attitude toward using is determined by perceived usefulness and perceived ease of use; and d) perceived ease of use affects perceived usefulness, which also mediates the effect of perceived ease of use on attitude toward using (Davis et al., 1989). Furthermore, TAM assumed that some external variables affect perceived usefulness and perceived ease of use, which also mediate the effect of external variables on attitude toward using. Thus, TAM provides a basis for relationships among external variables, beliefs, attitudes, intention to use, and actual use (Davis et al., 1989; Legris, Ingham \& Collerette, 2003), as shown in Figure 1.

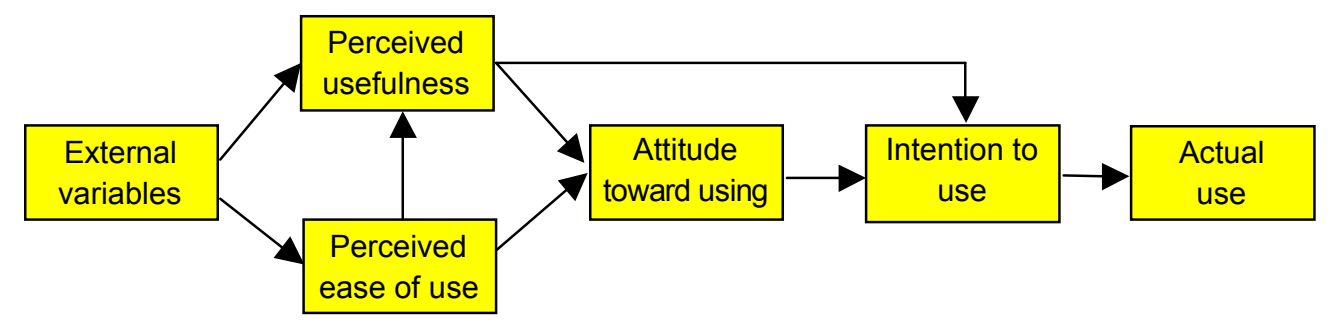

Figure 1: Technology acceptance model by Davis (Davis et al., 1989)

TAM, as proposed by Davis, was employed by many experimental studies related to information technology and systems, including e-learning (Ong \& Lai, 2006; Roca \& Gagné, 2008), mobile learning (Park, Nam \& Cha, 2011; Tai \& Ting, 2011), blended learning (Tselios, Daskalakis \& Papadopoulou, 2011), e-portfolio systems (Shroff, Deneen \& Ng, 2011), online community (Liu, Chen, Sun, Wible \& Kuo, 2010), world wide web (Moon \& Kim, 2001), mobile services (Lapczynski \& Calloway, 2006; Wang, Lin \& Luarn, 2006), PDAs (Arning \& Ziefle, 2007), and the wireless LAN (Yoon \& Kim, 2007). These studies found that TAM could efficiently predict and explain users' acceptance toward information technology (Legris et al., 2003).

Technology acceptance can be defined as a user's willingness, agreement, acceptance and continuous use of information technology and can be categorised into attitude acceptance and behaviour acceptance (Arning \& Ziefle, 2007). Attitude toward using, intention to use and actual use in TAM are indicators of technology acceptance. However, TAM can only be a relative indicator because data is self-assessed and not able to assess actual use (Legris et al., 2003). Therefore, many TAM-related studies (Roca \& Gagné, 2008; Wang et al., 2006; Yoon \& Kim, 2007) neglected actual use as an 
indicator of technology acceptance and examined relationships among external variables, perceived ease of use, perceived usefulness, attitude toward using and intention to use.

According to TAM as proposed by Davis, although perceived ease of use and perceived usefulness are the important determinants for an individual's acceptance and usage on information technology, the features of the technology, targeted users and the environment can also affect users' acceptance of new information technology (Moon \& Kim, 2001). Hence, many studies explained and predicted users' information technology acceptance based on TAM with external variables, and examined relationships between external variables and variables in TAM, such as self-efficacy (Wang et al., 2006), perceived quality (Roca et al., 2006), perceived value (Turel, Serenko \& Bontis, 2007), perceived playfulness (Moon \& Kim, 2001; Roca \& Gagné, 2008), and perceived convenience (Yoon \& Kim, 2007). TAM assumed that external variables affect perceived usefulness and perceived ease of use directly, and perceived ease of use and perceived usefulness mediate the technology acceptance. However, there were many studies finding that external variables not only affected the technology acceptance indirectly by perceived ease of use and perceived usefulness, but also affected technology acceptance directly (Burton-Jones \& Hubona, 2006; Moon \& Kim, 2001; Ong \& Lai, 2006; Yoon \& Kim, 2007).

\section{Perceived convenience}

To consumers, there are two kinds of convenience, which are product and service. A way to determine whether a product or service is convenient depends on time and effort (Berry, Seiders, \& Grewal, 2002). A product or service is considered to be convenient when it saves time for a user. On the other hand, a product or service is considered to be convenient when it lowers the cognitive, emotional and physical burdens for a user. Brown (1990) examined the convenience of a product or service by five dimensions including time, place, acquisition, use, and execution. However, Yoon and Kim (2007) believed that convenience in accessing technology is not definitely related to intention to use technology, and convenience in use is similar to ease of use in TAM. Therefore, Yoon and Kim (2007) examined the convenience of the wireless LAN based on the perspective of convenience suggested by Brown (1990), but only with three dimensions, namely time, place and execution. Yoon and Kim (2007) also defined perceived convenience as a level of convenience toward time, place and execution that one perceives when using the wireless network to complete a task.

Based on the perspective provided by Yoon and Kim (2007), perceived convenience, in the present study, was defined as a level of convenience toward time, place and execution that one feels during the participation in English mobile learning. Time convenience refers to a level of convenience toward time that one feels when performing a task in English mobile learning. In other words, if one can perform a task at any time, then one feels more convenient toward time. Place convenience refers to a level of convenience toward place that one feels when performing a task in English mobile learning. In other words, if one can perform a task at any place, then one feels more convenient toward place. Execution convenience refers to a level of convenience toward execution that one feels when performing a task in English mobile learning.

From the perspective of self-determination theory, perceived convenience is that users believe that a technology or a system is helpful to their task completion. To, Liao and 
Lin (2007) found that convenience value affected shopping motivation, which was a determinant of consumers' intention to shop on the Internet. Studies on RFID (Hossain \& Prybutok, 2008) and online shopping (Gupta \& Kim, 2007) revealed that perceived convenience was an antecedent factor that affected intention to use a mobile technology or system. However, a study on ubiquitous computing by Yoon and Kim (2007) extended TAM with perceived convenience and found that perceived convenience did not affect intention to use directly, and their extended TAM did not include attitude toward using as an indicator of technology acceptance. Furthermore, Yoon and Kim (2007) also found that perceived ease of use positively affected perceived convenience, and perceived convenience positively affected perceived usefulness. This finding was contradictory to Hossain and Prybutok (2008) who proposed that convenience included ease of use and usefulness. Therefore, relationships between perceived convenience and TAM variables require further examination.

\section{Research model and hypotheses}

Perceived convenience is one of the features of mobile learning, so it was employed for extending TAM, proposed by Davis, in the present study. Attitude toward using and continuance intention were indicators of technology acceptance in the extended TAM. Relationships among perceived convenience, perceived ease of use, perceived usefulness, attitude toward using mobile technology for English learning, and continuance intention to use mobile technology for English learning were examined in the present study. The research model and hypotheses in the present study, as shown in Figure 2, were proposed based on theories and related studies from literature review.

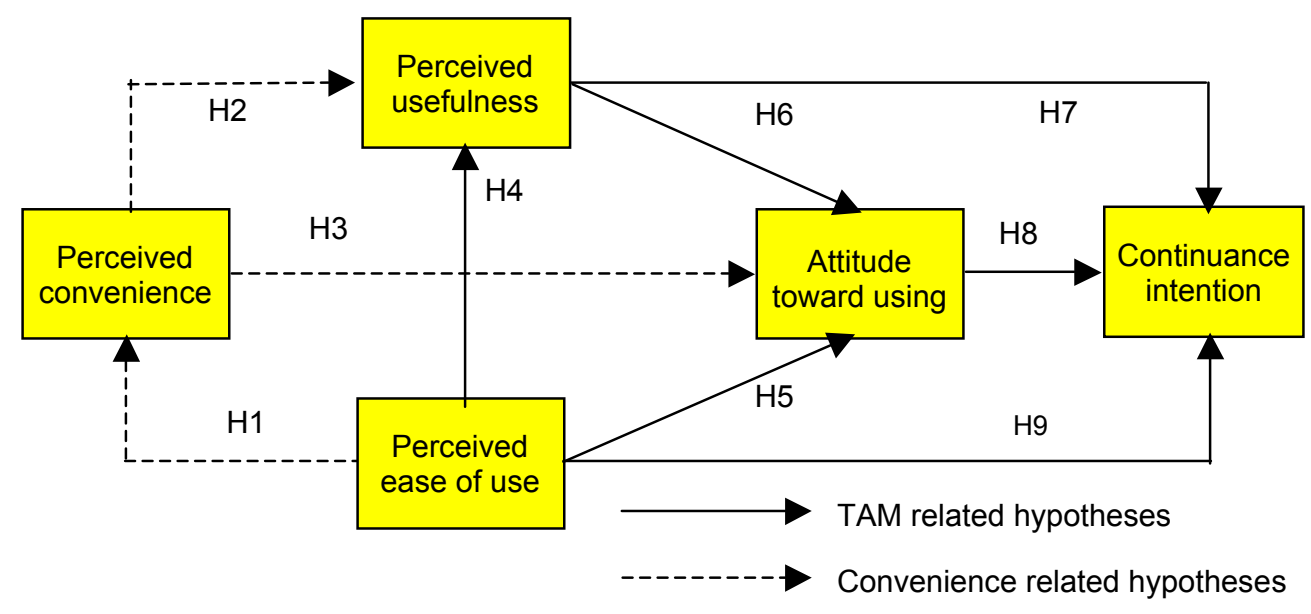

Figure 2: The research model and hypotheses

\section{Hypotheses on relationships between perceived convenience and TAM variables}

Yoon and Kim (2007) found that perceived ease of use positively affected perceived convenience in a wireless LAN acceptance model. So, Hypothesis 1 was established in the present study. 
$\mathrm{H}_{1}$ : Perceived ease of use positively affects perceived convenience in using mobile technology for English learning.

Yoon and Kim (2007) found that perceived convenience positively affected perceived usefulness. So, Hypothesis 2 was established in the present study.

$\mathrm{H}_{2}$ : Perceived convenience positively affects perceived usefulness in using mobile technology for English learning.

Yoon and Kim (2007) found that perceived convenience did not affect intention to use a wireless LAN directly, but they did not examine relationships between perceived convenience and attitude toward using a wireless LAN. According to the literature review, perceived ease of use was an antecedent factor that affects perceived convenience; perceived ease of use positively affected attitude toward using technology (Davis et al., 1989; Kuo \& Yen, 2009); and attitude toward using technology mediated the effect of perceived ease of use on intention to use technology (Castañeda, Muñoz-Leiva \& Luque, 2007; Davis et al., 1989). These results implied that perceived convenience might positively affect attitude toward using technology, so Hypothesis 3 was established in the present study.

$\mathrm{H}_{3}$ : Perceived convenience positively affects attitude toward using mobile technology for English learning.

\section{Hypotheses on relationships between TAM variables}

According to the TAM proposed by Davis, relationships between perceived ease of use, perceived usefulness, attitude toward using and intention to use were the following: a) perceived ease of use positively affected perceived usefulness; $b$ ) perceived usefulness and perceived ease of use positively affected attitude toward using; and c) perceived usefulness and attitude toward using positively affected intention to use. These relationships were proved by various technology acceptance studies on websites (Moon \& Kim, 2001; Castañeda et al., 2007) and mobile services (Kuo \& Yen, 2009). A study of ubiquitous computing by Yoon and Kim (2007) and a study of e-learning technology acceptance model by Ong, Lai and Wang (2004) found that perceived ease of use positively affected intention to use e-learning. Therefore, with an English mobile learning environment, relationships between perceived ease of use, perceived usefulness, attitude toward using and continuance intention to use mobile technology for English learning were hypothesised as the following:

$\mathrm{H}_{4}$ : Perceived ease of use positively affects perceived usefulness.

$\mathrm{H}_{5}$ : Perceived ease of use positively affects attitude toward using mobile technology for English learning.

$\mathrm{H}_{6}$ : Perceived usefulness positively affects attitude toward using mobile technology for English learning.

$\mathrm{H}_{7}$ : Perceived usefulness positively affects continuance intention to use mobile technology for English learning.

$\mathrm{H}_{8}$ : Attitude toward using positively affects continuance intention to use mobile technology for English learning.

$\mathrm{H}_{9}$ : Perceived ease of use positively affects continuance intention to use mobile technology for English learning. 


\section{Research method}

Participants in the present study were about the same age and did not have any experience in mobile learning. An influence from the age factor could occur, as Wang et al. (2009) found that the effect of effort expectancy on learners' intention to use mobile learning became moderate as one gets older. An influence from the experience factor also could occur, as Castañeda et al. (2007) found that determinants of intention to revisit the website, such as perceived ease of use and perceived usefulness, could be affected by users' experiences on the website. After participants engaged in the English mobile learning activities for two weeks, data was collected by a questionnaire that examined relationships among variables proposed in the model.

\section{Participants}

The college students in this study are suited to undertaking English mobile learning activities, as Wi-Fi is provided on campus, they take classes in different classrooms, and get more self-study time and spare time. The participants in the present study were 158 students ( 32 males and 126 females, aged from 16 to 22) from a technological college in middle part of Taiwan, who studied English with a reference book, called Studio Classroom as the supplementary text, and volunteered to participate in the English mobile learning. Their majors included Applied Foreign Language, Accounting and Information Management. The durations of their experiences in learning English, computing and the Internet were 8.6 years, 8.1 years and 7.4 years, respectively. About $86 \%$ of them did not have any experience in using a PDA.

\section{Instrument}

\section{Questionnaire}

Data for latent variables was collected by a questionnaire with a 7-point Likert-type scale. The response options were from 1 (strongly disagree) to 7 (strongly agree). The five latent variables from the previous studies were modified to measured variables in the present study. Each measurable variable was reviewed by two English teachers, five college students and two information technology experts to confirm that questions for each variable were clear enough and were described properly. The measurement of perceived convenience from Yoon and Kim (2007) was modified, and the measurement of perceived ease of use, perceived usefulness, attitude toward using and continuance intention to use from Davis (1989) were also modified. Operational definitions for the latent variables and the measured items are shown in Table 1.

\section{PDA and the English mobile learning system}

The English mobile learning in the present study was that students learned English by an English mobile learning system with a PDA. The PDA installed with Windows Mobile 6 was HP iPAQ 112 and included Wi-Fi and Bluetooth. The English mobile learning system was Mebook of Studio Classroom. Mebook was designed and developed by Taiwan's Soyong Corporation and was an e-book with the integration of text, sound, video and picture, which must be read through a reading software, MeReader.

\section{Procedure}

There were 53 PDAs for the experiment, so the 158 participants engaged in the English mobile learning activities in three groups. Each group had to complete three phases, 
namely introduction and first time use, actual use, and questionnaire, as shown in Table 2.

Table 1: Operational definitions for latent variables and measured items

\begin{tabular}{|c|c|c|}
\hline $\begin{array}{c}\text { Latent } \\
\text { variables }\end{array}$ & $\begin{array}{l}\text { Operational } \\
\text { definitions }\end{array}$ & Measured items \\
\hline \multirow{4}{*}{$\begin{array}{l}\text { Perceived } \\
\text { convenience }\end{array}$} & \multirow{4}{*}{$\begin{array}{l}\text { Perceived convenience is } \\
\text { defined as a level of } \\
\text { convenience toward } \\
\text { time, place and } \\
\text { execution that one feels } \\
\text { when pursuing a task } \\
\text { during the English } \\
\text { mobile learning. }\end{array}$} & $\begin{array}{l}\text { CO1 I can learn English at any time via the mobile } \\
\text { learning. }\end{array}$ \\
\hline & & \begin{tabular}{|l|l} 
CO2 I can learn English at any place via the mobile \\
learning.
\end{tabular} \\
\hline & & $\begin{array}{l}\text { CO3 The mobile learning is convenient for me to engage } \\
\text { in English learning. }\end{array}$ \\
\hline & & $\begin{array}{l}\text { CO4 I feel that mobile learning is convenient for me to } \\
\text { learn English. }\end{array}$ \\
\hline \multirow[t]{6}{*}{$\begin{array}{l}\text { Perceived } \\
\text { ease of use }\end{array}$} & \multirow{6}{*}{$\begin{array}{l}\text { Perceived ease of use } \\
\text { refers to a level of } \\
\text { easiness that one feels } \\
\text { when using English } \\
\text { mobile learning system. }\end{array}$} & \begin{tabular}{|l|l} 
EU1 & $\begin{array}{l}\text { Learning to operate English mobile learning system } \\
\text { would be ease for me. }\end{array}$ \\
\end{tabular} \\
\hline & & \begin{tabular}{|l|l|} 
EU2 & $\begin{array}{l}\text { I would find it easy get English mobile learning } \\
\text { system to do what I want it to do. }\end{array}$ \\
\end{tabular} \\
\hline & & \begin{tabular}{|l|l} 
EU3 & My interaction with English mobile learning system \\
& would be clear and understandable.
\end{tabular} \\
\hline & & \begin{tabular}{|l|l|} 
EU4 & $\begin{array}{l}\text { I would find English mobile learning system to be } \\
\text { flexible to interact with. }\end{array}$ \\
\end{tabular} \\
\hline & & \begin{tabular}{|l|l|} 
EU5 & $\begin{array}{l}\text { It would be easy for me to become skillful at using } \\
\text { English mobile learning system. }\end{array}$ \\
\end{tabular} \\
\hline & & \begin{tabular}{|l|l|} 
EU6 I would find English mobile learning system easy \\
to use.
\end{tabular} \\
\hline \multirow[t]{6}{*}{$\begin{array}{l}\text { Perceived } \\
\text { usefulness }\end{array}$} & \multirow{6}{*}{$\begin{array}{l}\text { Perceived usefulness is a } \\
\text { feeling that one holds } \\
\text { toward the improvement } \\
\text { in English mobile } \\
\text { learning. }\end{array}$} & \begin{tabular}{|l|l|} 
UF1 Using English mobile learning would enable me to \\
accomplish my learning English more quickly.
\end{tabular} \\
\hline & & \begin{tabular}{|l|l} 
UF2 Using English mobile learning would improve my \\
learning English performance.
\end{tabular} \\
\hline & & \begin{tabular}{|l|l|} 
UF3 Using English mobile learning would increase my \\
learning English productivity.
\end{tabular} \\
\hline & & \begin{tabular}{l|l} 
UF4 Using English mobile learning would enhance my \\
learning English effectiveness.
\end{tabular} \\
\hline & & \begin{tabular}{|l|l} 
UF5 Using English mobile learning would make it easier \\
to do my learning English.
\end{tabular} \\
\hline & & \begin{tabular}{l|l} 
UF6 I would find English mobile learning useful in my \\
learning English.
\end{tabular} \\
\hline \multirow{4}{*}{$\begin{array}{l}\text { Attitude } \\
\text { toward } \\
\text { using }\end{array}$} & \multirow{4}{*}{$\begin{array}{l}\text { Attitude toward using is } \\
\text { an attitude that one feels } \\
\text { positively toward the } \\
\text { English mobile learning. }\end{array}$} & \begin{tabular}{|l|l} 
AT1 & $\begin{array}{l}\text { Learning English via mobile learning is a good } \\
\text { idea. }\end{array}$ \\
\end{tabular} \\
\hline & & \begin{tabular}{|l|l|} 
AT2 & Learning English via mobile learning is a wise idea.
\end{tabular} \\
\hline & & \begin{tabular}{|l} 
AT3 $\begin{array}{l}\text { Learning English via mobile learning is a pleasant } \\
\text { idea. }\end{array}$ \\
\end{tabular} \\
\hline & & $\begin{array}{l}\text { AT4 } \begin{array}{l}\text { Learning English via mobile learning is a positive } \\
\text { idea. }\end{array} \\
\end{array}$ \\
\hline \multirow{3}{*}{$\begin{array}{l}\text { Continuance } \\
\text { intention to } \\
\text { use }\end{array}$} & \multirow{3}{*}{$\begin{array}{l}\text { Continuance intention to } \\
\text { use refers to one's } \\
\text { willingness to continue } \\
\text { to learn English via } \\
\text { mobile learning after the } \\
\text { English mobile learning. }\end{array}$} & \begin{tabular}{|l|l} 
IN1 & $\begin{array}{l}\text { In next weeks, I would like to learn English via } \\
\text { mobile learning. }\end{array}$ \\
\end{tabular} \\
\hline & & \begin{tabular}{|l|l} 
IN2 & $\begin{array}{l}\text { In next weeks, I predict that I will learn English via } \\
\text { mobile learning. }\end{array}$ \\
\end{tabular} \\
\hline & & \begin{tabular}{|l|l|} 
IN3 & $\begin{array}{l}\text { In next weeks, I plan to learn English via mobile } \\
\text { learning. }\end{array}$ \\
\end{tabular} \\
\hline
\end{tabular}

As most participants did not have any experience in using PDA and English mobile learning, the researcher provided an orientation session explaining the research purpose and procedure, and the English mobile learning system. After participants 
confirmed that they all knew how to use PDA and the English mobile learning system, they could engage in the readings and listening practices by using a PDA at any spot in the classroom. Participants were required to complete questionnaires after they engaged in the English mobile learning based on their own pace and learning needs. The course ran from the middle of May to the end of May 2011 over a period of approximately 2 weeks.

Table 2: Procedure

\begin{tabular}{|c|c|c|c|}
\hline Phase & Place & Procedure & Time \\
\hline \multirow{4}{*}{$\begin{array}{l}\text { Introduction } \\
\text { and first time } \\
\text { use }\end{array}$} & \multirow[t]{4}{*}{ Classroom } & A PDA is provided to each participant & $10 \mathrm{mins}$ \\
\hline & & An orientation for the research purpose and procedure & $10 \mathrm{mins}$ \\
\hline & & $\begin{array}{l}\text { An orientation for the introduction of PDA and the } \\
\text { English mobile learning system }\end{array}$ & $20 \mathrm{mins}$ \\
\hline & & First time use: Reading articles and listening practice & $20 \mathrm{mins}$ \\
\hline Actual use & Any place & $\begin{array}{l}\text { Participants engage in the English mobile learning based } \\
\text { on their own pace and learning needs. }\end{array}$ & 2 weeks \\
\hline Questionnaire & Classroom & $\begin{array}{l}\text { After the two-week English mobile learning, } \\
\text { questionnaires are administered to participants. }\end{array}$ & 20 mins \\
\hline
\end{tabular}

\section{Data analysis}

Structural equation modeling (SEM) is a statistical method that combines factor analysis and path analysis, provides theory construction and analyses relationships among variables, so SEM was employed in the present study to examine the research model and hypotheses. The covariance analysing software, LISREL and AMOS, provides SEM analysis (Chin, 1988). The component analysing software, PLS-Graph and SmartPLS, also provides SEM analysis. The component analysis analyses relationships among latent variables through path modeling based on the partial least squares (PLS).

Sørebø, Halvari, Gulli and Kristiansen (2009) pointed out that PLS is a second version of the regression method that combines confirmatory factor analysis and linear regression and can run measurement model and structural model analysis simultaneously. PLS is especially suitable for analyses with small or medium sample sizes (Lee, Cheung \& Chen, 2007), whereas LISREL is suitable for analyses with large sample sizes (Hulland, 1999). Therefore, researchers in fields related to information management (Burton-Jones \& Hubona, 2006; Turel et al., 2007) and education (Annear \& Yates, 2010; Sørebø et al., 2009; Tselios et al., 2011) have tended to perform the model analysis for latent variables by PLS.

The sample size for the present study was 158 participants, which implied a medium sample size, so the statistical analysing software, SmartPLS 2.0 (Ringle, Wende \& Will, 2005), was employed. PLS examines the significance of path coefficients in the model analysis by conducting different resampling methods. SmartPLS performed significance of path coefficient tests by conducting bootstrapping sampling (Annear \& Yates, 2010) in order to provide $t$-test values for path coefficients in the model analysis. The samples of bootstrapping in the present study were set to be 300 .

\section{Results}

Although PLS examines parameters among latent variables and relationships between measured variables and latent variables simultaneously, the model analysis and 
explanation of PLS must engage in both measurement model and structural model analyses. This helps one to analyse relationships among latent variables and predictability of the model more precisely (Haffer \& Kristensen, 2008; Hulland, 1999). Therefore, this study performed the measurement model analysis for evaluating reliability and validity of latent variables first, and then performed the structural model analysis for examining the research hypotheses and the explanatory power of the model.

\section{Measurement model analysis}

Measurement model analysis is used to examine whether all the measured variables measure what a latent variable attempts to measure in the research model or have loadings in the other latent variables. So, the present study examined the measurement model from three perspectives suggested by Hulland (1999), which were: a) individual item reliability; b) convergent validity; and c) discriminant validity. Reliability and validity analyses based on these three perspectives are described below.

Individual item reliability is used to evaluate factor loadings of measured variables on latent variables. Hulland (1999) argued that a low factor loading represents a low explanatory power of the model, and suggested that factor loadings of measured variables should be greater than 0.7 . Table 3 presents an overall good reliability of the measured variables in the present study because all the factor loadings in the latent variables ranged from 0.8 to 0.96 .

Table 3: Reliability and validity analysis of latent variables

\begin{tabular}{|c|c|c|c|c|c|c|}
\hline \multirow{2}{*}{ Latent variable } & \multirow{2}{*}{$\begin{array}{c}\text { Measured } \\
\text { variable }\end{array}$} & \multirow{2}{*}{ Average } & \multirow{2}{*}{$\begin{array}{l}\text { Standard } \\
\text { deviation }\end{array}$} & \multirow{2}{*}{$\begin{array}{l}\text { Factor } \\
\text { loading }\end{array}$} & \multicolumn{2}{|c|}{ Convergent validity } \\
\hline & & & & & CR & AVE \\
\hline \multirow{4}{*}{$\begin{array}{l}\text { Perceived } \\
\text { convenience }\end{array}$} & CO1 & 5.53 & 1.12 & 0.87 & \multirow[t]{4}{*}{0.93} & \multirow[t]{4}{*}{0.77} \\
\hline & $\mathrm{CO} 2$ & 5.70 & 1.16 & 0.84 & & \\
\hline & $\mathrm{CO} 3$ & 5.66 & 1.06 & 0.89 & & \\
\hline & $\mathrm{CO} 4$ & 5.66 & 1.07 & 0.90 & & \\
\hline \multirow{6}{*}{$\begin{array}{l}\text { Perceived ease } \\
\text { of use }\end{array}$} & EU1 & 5.58 & 1.04 & 0.82 & \multirow[t]{6}{*}{0.93} & \multirow[t]{6}{*}{0.69} \\
\hline & EU2 & 5.33 & 1.07 & 0.80 & & \\
\hline & EU3 & 5.10 & 1.15 & 0.86 & & \\
\hline & EU4 & 5.28 & 1.13 & 0.82 & & \\
\hline & EU5 & 5.29 & 1.22 & 0.84 & & \\
\hline & EU6 & 5.41 & 1.13 & 0.85 & & \\
\hline \multirow{6}{*}{$\begin{array}{l}\text { Perceived } \\
\text { usefulness }\end{array}$} & UF1 & 5.18 & 1.17 & 0.86 & \multirow[t]{6}{*}{0.95} & \multirow[t]{6}{*}{0.76} \\
\hline & UF2 & 4.92 & 1.17 & 0.87 & & \\
\hline & UF3 & 5.09 & 1.31 & 0.86 & & \\
\hline & UF4 & 5.23 & 1.26 & 0.87 & & \\
\hline & UF5 & 5.05 & 1.16 & 0.87 & & \\
\hline & UF6 & 5.21 & 1.26 & 0.89 & & \\
\hline \multirow{4}{*}{$\begin{array}{l}\text { Attitude toward } \\
\text { using }\end{array}$} & AT1 & 5.54 & 1.13 & 0.94 & \multirow[t]{4}{*}{0.96} & \multirow[t]{4}{*}{0.84} \\
\hline & AT2 & 5.32 & 1.19 & 0.91 & & \\
\hline & AT3 & 5.47 & 1.14 & 0.89 & & \\
\hline & AT4 & 5.49 & 1.14 & 0.94 & & \\
\hline \multirow{3}{*}{$\begin{array}{l}\text { Continuance } \\
\text { intention to use }\end{array}$} & IN1 & 5.16 & 1.31 & 0.93 & \multirow[t]{3}{*}{0.97} & \multirow[t]{3}{*}{0.90} \\
\hline & IN2 & 5.09 & 1.33 & 0.96 & & \\
\hline & IN3 & 5.04 & 1.35 & 0.95 & & \\
\hline
\end{tabular}

Composite reliability (CR) and average variance extracted (AVE) are the two main indicators used to evaluate convergent validity (Lee et al., 2007). A composite 
reliability of a latent variable is formed by reliabilities of all the measured variables, which represents an internal consistency of a latent variable (or consistency between measured variables in a latent variable). The higher the composite reliability, the higher is the internal consistency of a latent variable. Fornell and Larcker (1981) suggested that composite reliability should be greater than 0.7 . Table 3 shows a good internal consistency for each latent variable, ranging from 0.93 to 0.97 . An average variance extracted of a latent variable is to calculate the average variance explained power of measured variables on the latent variable. The higher the average variance extracted, the higher is the convergent validity. Fornell and Larcker (1981) suggested that an average variance extracted should be greater than 0.5 . Table 3 shows that the average variance extracted for each latent variable ranged from 0.69 to 0.9 . Based on the analysis, latent variables in the present study possessed a good convergent validity.

Fornell and Larcker (1981) suggested that discriminant validity can be calculated by the square root of average variance extracted (AVE) of each latent variable and the correlation coefficient among latent variables. Discriminant validity exists when the square root of average variance extracted of a latent variable is greater than the correlation coefficients between the latent variable and the other latent variables. Table 4 shows that the square roots of average variance extracted were greater than the correlation coefficients between the latent variable and the other latent variables, meaning that discriminant validity existed among latent variables in the present study.

Table 4: The square root of AVE of each latent variable and the correlation coefficient between the latent variable and the other latent variables

\begin{tabular}{|l|c|c|c|c|c|}
\hline Latent variable & $\begin{array}{c}\text { Perceived } \\
\text { convenience }\end{array}$ & $\begin{array}{c}\text { Perceived ease } \\
\text { of use }\end{array}$ & $\begin{array}{c}\text { Perceived } \\
\text { usefulness }\end{array}$ & $\begin{array}{c}\text { Attitude } \\
\text { toward using }\end{array}$ & $\begin{array}{c}\text { Continuance } \\
\text { intention to use }\end{array}$ \\
\hline $\begin{array}{l}\text { Perceived } \\
\text { convenience }\end{array}$ & $\mathbf{0 . 8 8}$ & $\mathbf{0 . 8 3}$ & & & \\
\hline $\begin{array}{l}\text { Perceived ease } \\
\text { of use }\end{array}$ & 0.57 & 0.65 & $\mathbf{0 . 8 7}$ & & \\
\hline $\begin{array}{l}\text { Perceived } \\
\text { usefulness }\end{array}$ & 0.61 & 0.64 & 0.75 & $\mathbf{0 . 9 2}$ & \\
\hline $\begin{array}{l}\text { Attitude toward } \\
\text { using }\end{array}$ & 0.63 & 0.54 & 0.69 & 0.69 & $\mathbf{0 . 9 5}$ \\
\hline $\begin{array}{l}\text { Continuance } \\
\text { intention to use }\end{array}$ & 0.57 & & & & \\
\hline
\end{tabular}

Note: Bold numbers in diagonal lines are square root of AVE of each latent variable; numbers in non-diagonal lines are correlation coefficient between the latent variable and the other latent variables.

Based on the analyses from the three indicators, the latent variables in the research model possessed good reliability and validity, which was qualified to perform the hypothesis test about the correlations among the latent variables and predictability of the model's explanatory power.

\section{Structural model analysis}

Structural model analysis is mainly to examine path coefficients and $R^{2}$ among latent variables in the research model. Path coefficients measure the relative strength and sign of causal relationships among latent variables, whereas $R^{2}$ is the percentage of total variance explained of exogenous variable (or independent variables) on endogenous variables (or dependent variables) and represents the predictability of the 
research model. Path coefficients and $R^{2}$ represent the matching level between structural model and experimental data. Figure 3 is the summary of the structural model analysis in the present study. The path coefficient is shown for each path, with the significance as asterisked, and the $R^{2}$ is shown under each endogenous variable. Table 5 shows the path coefficients, $t$ values and $p$ values among latent variables, and the results of the hypothesis test.

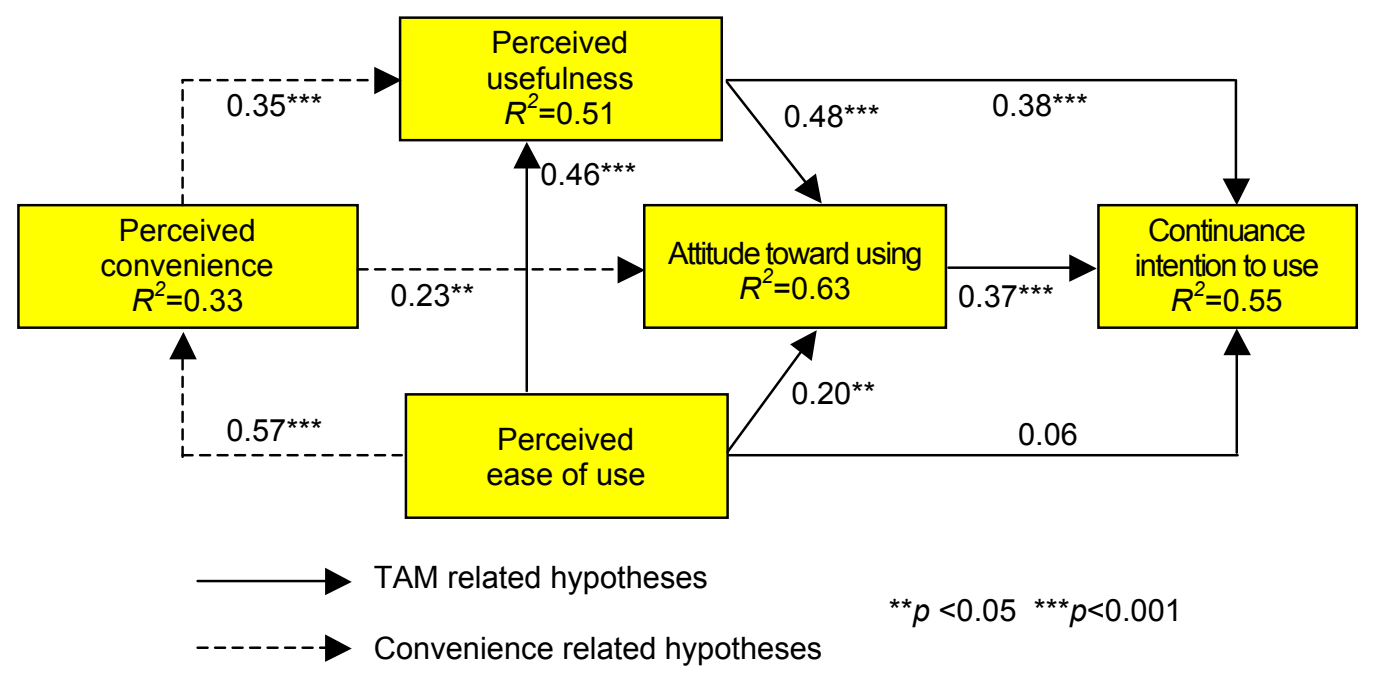

Figure 3: Structural model analysing result

Table 5: Path coefficients and results of the hypothesis test

\begin{tabular}{|c|l|c|c|c|}
\hline Hypothesis & \multicolumn{1}{|c|}{ Path } & Path coefficient & $t$ value & Result \\
\hline 1 & $\begin{array}{l}\text { perceived ease of use } \rightarrow \\
\text { perceived convenience }\end{array}$ & 0.57 & $9.98^{\star * *}$ & Accept \\
\hline 2 & $\begin{array}{l}\text { perceived convenience } \rightarrow \\
\text { perceived usefulness }\end{array}$ & 0.35 & $4.28^{\star * *}$ & Accept \\
\hline 3 & $\begin{array}{l}\text { perceived convenience } \rightarrow \\
\text { attitude toward using }\end{array}$ & 0.23 & $3.06^{* *}$ & Accept \\
\hline 4 & $\begin{array}{l}\text { perceived ease of use } \rightarrow \\
\text { perceived usefulness }\end{array}$ & 0.46 & $6.52^{* * *}$ & Accept \\
\hline 5 & $\begin{array}{l}\text { perceived ease of use } \rightarrow \\
\text { attitude toward using }\end{array}$ & 0.20 & $2.91^{* *}$ & Accept \\
\hline 6 & $\begin{array}{l}\text { perceived usefulness } \rightarrow \\
\text { attitude toward using }\end{array}$ & 0.48 & $6.02^{* * *}$ & Accept \\
\hline 7 & $\begin{array}{l}\text { perceived usefulness } \rightarrow \\
\text { continuance intention to use }\end{array}$ & 0.38 & $3.81^{* * *}$ & Accept \\
\hline 8 & $\begin{array}{l}\text { attitude toward using } \rightarrow \\
\text { continuance intention to use }\end{array}$ & 0.37 & $4.66^{* * *}$ & Accept \\
\hline 9 & $\begin{array}{l}\text { perceived ease of use } \rightarrow \\
\text { continuance intention to use }\end{array}$ & 0.06 & 0.62 & Reject \\
\hline${ }^{* *} p<0.01,{ }^{* * *} p<0.001$ & & \\
&
\end{tabular}

According to Table 5, the test results for Hypotheses 1 to 8 were significant. The significant results included: a) perceived ease of use positively affected perceived convenience; b) perceived convenience positively affected perceived usefulness; c) 
perceived convenience positively affected attitude toward using; d) perceived ease of use positively affected perceived usefulness; e) perceived ease of use positively affected attitude toward using; f) perceived usefulness positively affected attitude toward using; g) perceived usefulness positively affected continuance intention to use; and $\mathrm{h}$ ) attitude toward using positively affected continuance intention to use. The coefficients for the eight hypotheses were $0.57,0.35,0.23,0.46,0.20,0.48,0.38$ and 0.37 , respectively. However, the test result for Hypothesis 9 was not significant; meaning that perceived ease of use and continuance intention to use did not have a causal relationship.

Hulland (1999) pointed out that LISREL and other covariance structure analyses examine the structure model based on the overall model fit, whereas PLS examines the model goodness-of-fit based on $R^{2}$ of endogenous variables, because PLS focuses mainly on minimisation of error or maximisation of variance explained in all endogenous variables. As shown in Figure $3, R^{2}$ for the four endogenous variables in the present model, including continuance intention to use, attitude toward using, perceived usefulness and perceived convenience, were $0.55,0.63,0.51$ and 0.33 , respectively. In other words, perceived usefulness and attitude toward using explained about $55 \%$ of the total variance in continuance intention to use; perceived convenience, perceived usefulness and perceived ease of use explained about $63 \%$ of the total variance in attitude toward using; perceived convenience and perceived ease of use explained about $51 \%$ of the total variance in perceive usefulness; and perceived ease of use explained about $33 \%$ of the total variance in perceived convenience. Since the research model explained more than $50 \%$ of the total variance in attitude toward using and continuance intention to use, the research model held a good predictability and explanatory power for the acceptance of the English mobile learning.

\section{Discussion}

\section{Research hypotheses}

For perceived convenience, the results revealed that perceived ease of use positively affected perceived convenience, which was consistent with the findings by Yoon and Kim (2007), meaning that the easier the use of the English mobile learning system, the more convenient it will be perceived by a user. Perceived convenience positively affected perceived usefulness, which was also consistent with Yoon and Kim (2007), meaning that the more convenient the English mobile learning system, the more useful one perceived it to be. Furthermore, it was also found that perceived convenience positively affected attitude toward using, revealing that the more convenient the English mobile learning system, the more positive the attitude toward using the English mobile learning system.

For the TAM relative hypotheses, results showed that: a) perceived ease of use positively affected perceived usefulness; b) perceived ease of use and perceived usefulness positively affected attitude toward using; c) perceived usefulness and attitude toward using positively affected continuance intention to use; but d) perceived ease of use did not affect continuance intention to use directly. These results were consistent with the findings on TAM proposed by Davis (1989). Even though a number of studies have shown that perceived ease of use positively affected intention to use (Ong \& Lai, 2006; Wang et al., 2006; Yoon \& Kim, 2007), the present study showed that perceived ease of use did not affect intention to use directly. Whether or not users' 
experiences moderate the effects of external variables on intention to use or using behavior (Castañeda et al., 2007) should be further examined.

\section{Effects}

Effects among latent variables include direct effects and indirect effects, so the overall effect from latent variables is the summation of direct effects and indirect effects. Effects among latent variables in the present study are shown in Table 6. As shown in Table 6, perceived ease of use was the antecedent factor that affected perceived convenience; perceived ease of use and perceived convenience were the antecedent factors that affected perceived usefulness; perceived ease of use had a greater overall effect on perceived usefulness than that on perceived convenience; and the order (from greatest to smallest) for the direct effects of the latent variables on attitude toward using was perceived usefulness, perceived convenience and perceived ease of use. Since perceived ease of use had a direct effect on attitude toward using and had an indirect effect on attitude toward using through perceived convenience and perceived usefulness, the order (from great to small) for the overall effects of the latent variables that affected attitude toward using was perceived ease of use, perceived usefulness and perceived convenience.

Although perceived convenience and perceived ease of use did not affect continuance intention to use directly, these two factors affected continuance intention to use indirectly through perceived usefulness and attitude toward using. So, the order (from greatest to smallest) for the overall effects of the latent variables that affected continuance intention to use was perceived usefulness, perceived ease of use, attitude toward using and perceived convenience. Therefore, perceived convenience, perceived ease of use and perceived usefulness were the antecedent factors that affected attitude toward using and continuance intention to use of the English mobile learning system.

Table 6: Effects between each latent variable

\begin{tabular}{|l|c|c|c|c|c|c|c|c|c|c|c|c|}
\cline { 2 - 13 } & \multicolumn{3}{|c|}{$\begin{array}{c}\text { Perceived } \\
\text { convenience }\end{array}$} & \multicolumn{3}{c|}{$\begin{array}{c}\text { Perceived } \\
\text { usefulness }\end{array}$} & \multicolumn{3}{c|}{$\begin{array}{c}\text { Attitude } \\
\text { toward using }\end{array}$} & \multicolumn{3}{c|}{$\begin{array}{c}\text { Continuance } \\
\text { intention to use }\end{array}$} \\
\cline { 2 - 14 } & $\mathrm{D}$ & $\mathrm{I}$ & $\mathrm{O}$ & $\mathrm{D}$ & $\mathrm{I}$ & $\mathrm{O}$ & $\mathrm{D}$ & $\mathrm{I}$ & $\mathrm{O}$ & $\mathrm{D}$ & $\mathrm{I}$ & $\mathrm{O}$ \\
\hline Perceived convenience & -- & -- & -- & 0.35 & -- & 0.35 & 0.23 & 0.17 & 0.40 & -- & 0.28 & 0.28 \\
\hline Perceived ease of use & 0.57 & -- & 0.57 & 0.46 & 0.19 & 0.65 & 0.20 & 0.44 & 0.64 & 0.06 & 0.48 & 0.54 \\
\hline Perceived usefulness & -- & -- & -- & -- & -- & -- & 0.48 & -- & 0.48 & 0.38 & 0.18 & 0.56 \\
\hline Attitude toward using & -- & -- & -- & -- & -- & -- & -- & -- & -- & 0.37 & -- & 0.37 \\
\hline
\end{tabular}

Note: $\mathrm{D}=$ Direct; $\mathrm{I}=$ Indirect; $\mathrm{O}=$ Overall

\section{Conclusions and implications}

Convenience is one of the features of mobile learning, so perceived convenience was employed as an external variable in the extended TAM for examining the technology acceptance model of the English mobile learning activities. One of important research results revealed that: perceived convenience positively affected perceived usefulness and attitude toward using; however, it did not affect continuance intention to use directly but only affected continuance intention to use indirectly through perceived usefulness and attitude toward using. Therefore, in the English mobile learning environment, perceived convenience was one of the antecedent factors that affected attitude toward using and continuance intention to use. The acceptance model of the English mobile learning proposed by the present study could explain about $63 \%$ of the 
total variance in attitude toward using and about $55 \%$ of the total variance in continuance intention to use. Overall, the present model was good in predicting and explaining users' acceptance of English mobile learning.

\section{Research implications}

Since mobile learning is mobile and ubiquitous, users are able to learn without any time and place restrictions. This way to learn is a new trend in the future of e-learning. The researchers in the present study proposed an extended TAM with perceived convenience and employed SmartPLS as an analysing tool for SEM to examine the predictability and explanatory power of the model on English mobile learning. The results provided meaningful relationships among the variables in the TAM including perceived convenience, perceived ease of use, perceived usefulness, attitude toward using and continuance intention to use. In the past, there have been only a few studies examining the acceptance of mobile learning after participants learned with a particular mobile system, and there have been few mobile learning related studies examining relationships between perceived convenience and other variables in the TAM. Therefore, the findings in the present study provided a reference for the future TAM and mobile learning related studies.

\section{Practical implications}

It was found that perceived usefulness was an important factor that affected users' continuance intention to use, so enhancing the usefulness of the English mobile learning activities would enhance users' continuance intention to use. Although perceived convenience and perceived ease of use affected continuance intention to use indirectly through perceived usefulness and attitude toward using, perceived convenience and perceived ease of use were the antecedent factors that affected perceived usefulness and attitude toward using. Consequently, enhancing the convenience and ease of use of the English mobile learning system is helpful to facilitate usefulness and attitude toward using, and therefore continuance intention to use is enhanced, which could be noted by designers of mobile learning activities.

\section{Research limitations and future work}

In this study, participants with about the same ages engaged in the learning activity with a PDA and a particular English mobile learning system for two weeks, and the researchers analysed the data from them based on SmartPLS. Therefore, it was not appropriate to generalise the study results to other systems, subjects and participants with different ages. Future studies can focus on other mobile devices, systems and participants. Furthermore, the data collected from participants can be different due to the usage and increased experience (Venkatesh, Morris, Davis \& Davis, 2003). Therefore, future studies could focus on longitudinal research, which is helpful for predicting users' long-run belief and behaviour, and can improve the comprehension of causal relationships among variables. Moreover, the variable actual use behaviours, was not included in the present English mobile learning model. Future studies can include actual use behaviours or other external variables that affect the acceptance of mobile learning, in order to predict and explain users' acceptance of mobile learning. Finally, it was found that perceived ease of use did not affect continuance intention to use directly in the present study. Whether this was due to users' possession of computers or learning system use experiences should be examined further. 


\section{References}

Annear, K. D. \& Yates, G. C. R. (2010). Restrictive and supportive parenting: Effects on children's school affect and emotional responses. Australian Educational Researcher, 37(1), 63-82. http: / / dx.doi.org/10.1007/BF03216914

Arning, K. \& Ziefle, M. (2007). Understanding age differences in PDA acceptance and performance. Computers in Human Behavior, 23(6), 2904-2927. http: / / dx.doi.org/10.1016/j.chb.2006.06.005

Berry, L. L., Seiders, K. \& Grewal, D. (2002). Understanding service convenience. Journal of Marketing, 66(3), 1-17. http:// www.jstor.org/stable/3203451

Brown, L. G. (1990). Convenience in services marketing. Journal of Services Marketing, 4(1), 53-59. http: / / dx.doi.org/10.1108/EUM0000000002505

Burton-Jones, A. \& Hubona, G. S. (2006). The mediation of external variables in the technology acceptance model. Information $\mathcal{E}$ Management, 43(6), 706-717. http: / / dx.doi.org/10.1016/j.im.2006.03.007

Castañeda, J. A., Muñoz-Leiva, F. \& Luque, T. (2007). Web acceptance model (WAM): Moderating effects of user experience. Information $\mathcal{E}$ Management, 44(4), 384-396. http: / / dx.doi.org/10.1016/j.im.2007.02.003

Chen, C.-M. \& Chung, C.-J. (2008). Personalized mobile English vocabulary learning system based on item response theory and learning memory cycle. Computers $\mathcal{E}$ Education, 51(2), 624645. http:/ / dx.doi.org/10.1016/j.compedu.2007.06.011

Chin, W. W. (1998). Issues and opinion on structural equation modeling. MIS Quarterly, 22(1), viixvi. http:/ / aisel.aisnet.org/ misq/ vol22 / iss1/3/

Chinnery, G. M. (2006). Going to the MALL: Mobile assisted language learning. Language Learning E Technology, 10(1), 9-16. http: / /llt.msu.edu/vol10num1/emerging/default.html

Davis, F. D. (1989). Perceived usefulness, perceived ease of use, and user acceptance of information technology. MIS Quarterly, 13(3), 319-340. http: / dx.doi.org/10.2307 / 249008

Davis, F. D., Bagozzi, R. P. \& Warshaw, P. R. (1989). User acceptance of computer technology: A comparison of two theoretical models. Management Science, 35(8), 982-1003. http: / / www.jstor.org/ stable/2632151

Fornell, C. \& Larcker, D. F. (1981). Evaluating structural equation models with unobservable variables and measurement error. Journal of Marketing Research, 18(1), 39-50. http: / / www.jstor.org/ stable/3151312

Gupta, S. \& Kim, H.-W. (2007). The moderating effect of transaction experience on the decision calculus in on-line repurchase. International Journal of Electronic Commerce, 12(1), 127-158. http: / / dx.doi.org/10.2753/JEC1086-4415120105

Haffer, R. \& Kristensen, K. (2008). Developing versus developed companies in business excellence initiatives. Total Quality Management \& Business Excellence, 19(7-8), 763-775. http: / / dx.doi.org/10.1080/14783360802159428

Hossain, M. M. \& Prybutok, V. R. (2008). Consumer acceptance of RFID technology: An exploratory study. IEEE Transactions on Engineering Management, 55(2), 316-328. http: / / dx.doi.org/10.1109/ TEM.2008.919728

Hulland, J. (1999). Use of partial least squares (PLS) in strategic management research: A review of four recent studies. Strategic Management Journal, 20(2), 195-204. http: / / dx.doi.org/10.1002 / (SICI)1097-0266(199902)20:2<195::AID-SMJ13>3.0.CO;2-7

Kuo, Y.-F. \& Yen, S.-N. (2009). Towards an understanding of the behavioral intention to use 3G mobile value-added services. Computers in Human Behavior, 25(1), 103-110. http:/ / dx.doi.org/10.1016/j.chb.2008.07.007 
Lapczynski, P. H. \& Calloway, L. J. (2006). A scheme of technology acceptance for mobile computing. In M. Khosrow-Pour (Ed.), Emerging trends and challenges in information technology management (p.208-212). Hershey, PA: Idea Group Inc.

Lea, S. \& Callaghan, L. (2011). Enhancing health and social care placement learning through mobile technology. Educational Technology \& Society, 14(1), 135-145. http: / / www.ifets.info/journals/14_1/12.pdf

Lee, M. K. O., Cheung, C. M. K. \& Chen, Z. (2007). Understanding user acceptance of multimedia messaging services: An empirical study. Journal of the American Society for Information Science E Technology, 58(13), 2066-2077. http: / / dx.doi.org/10.1002/asi.v58:13

Legris, P., Ingham, J. \& Collerette, P. (2003). Why do people use information technology? A critical review of the technology acceptance model. Information \& Management, 40(3), 191-204. http: / / dx.doi.org/10.1016/S0378-7206(01)00143-4

Liu, I. F., Chen, M. C., Sun, Y. S., Wible, D. \& Kuo, C. H. (2010). Extending the TAM model to explore the factors that affect intention to use an online learning community. Computers $\mathcal{E}$ Education, 54, 600-610. http: / / dx.doi.org/10.1016/j.compedu.2009.09.009

Moon, J.-W. \& Kim, Y.-G. (2001). Extending the TAM for a World-Wide-Web context. Information $\mathcal{E}$ Management, 38(4), 217-230. http: / / dx.doi.org/10.1016/S0378-7206(00)00061-6

Ong, C.-S. \& Lai, J.-Y. (2006). Gender differences in perceptions and relationships among dominants of e-learning acceptance. Computers in Human Behavior, 22(5), 816-829. http: / / dx.doi.org/10.1016/j.chb.2004.03.006

Ong, C.-S., Lai, J.-Y. \& Wang, Y.-S. (2004). Factors affecting engineers' acceptance of asynchronous e-learning systems in high-tech companies. Information $\mathcal{E}$ Management, 41(6), 795-804. http:/ / dx.doi.org/10.1016/j.im.2003.08.012

Park, S. Y., Nam, M. W. \& Cha, S. B. (2011). University students' behavioral intention to use mobile learning: Evaluating the technology acceptance model. British Journal of Educational Technology, (Article first published online: 4 Oct 2011). http:/ / dx.doi.org/10.1111/j.14678535.2011.01229.x

Peng, H., Su, Y.-J., Chou, C. \& Tsai, C.-C. (2009). Ubiquitous knowledge construction: Mobile learning re-defined and a conceptual framework. Innovations in Education $\mathcal{E}$ Teaching International, 46(2), 171-183. http:/ / dx.doi.org/10.1080/14703290902843828

Pituch, K. A. \& Lee, Y.-K. (2006). The influence of system characteristics on e-learning use. Computers \& Education, 47(2), 222-244. http:/ / dx.doi.org/10.1016/j.compedu.2004.10.007

Ringle, C. M., Wende, S. \& Will, S. (2005). SmartPLS 2.0. Hamburg, Germany: University at Hamburg. http:/ / www.smartpls.de/

Roca, J. C. \& Gagné, M. (2008). Understanding e-learning continuance intention in the workplace: A self-determination theory perspective. Computers in Human Behavior, 24(4), 1585-1604. http:/ / dx.doi.org/10.1016/j.chb.2007.06.001

Roca, J. C., Chiu, C.-M. \& Martinez, F. J. (2006). Understanding e-learning continuance intention: An extension of the technology acceptance model. International Journal of Human-Computer Studies, 64(8), 683-696. http: / / dx.doi.org/10.1016/j.ijhcs.2006.01.003

Shih, J.-L., Chuang, C.-W. \& Hwang, G.-J. (2010). An inquiry-based mobile learning approach to enhancing social science learning effectiveness. Educational Technology \& Society, 13(4), 50-62. http: / / www.ifets.info/journals/13_4/6.pdf

Shin, D.-H. (2007). User acceptance of mobile Internet: Implication for convergence technologies. Interacting with Computers, 19(4), 472-483. http: / / dx.doi.org/10.1016/j.intcom.2007.04.001

Shroff, R. H., Deneen, C. D. \& Ng, E. M. W. (2011). Analysis of the technology acceptance model in examining students' behavioural intention to use an e-portfolio system. Australasian Journal of Educational Technology, 27(4), 600-618. http:/ / www.ascilite.org.au/ ajet/ ajet27/ shroff.html 
Sørebø, Ø., Halvari, H., Gulli, V. F. \& Kristiansen, R. (2009). The role of self-determination theory in explaining teachers' motivation to continue to use e-learning technology. Computers $\mathcal{E}$ Education, 53(4), 1177-1187. http: / / dx.doi.org/10.1016/j.compedu.2009.06.001

Tai, Y. \& Ting, Y. L. (2011). Adoption of mobile technology for language learning: Teacher attitudes and challenges. The JALT CALL Journal, 7(1), 3-18. http:/ / www.jaltcall.org/journal/articles/7_1_Tai.pdf

Thornton, P. \& Houser, C. (2005). Using mobile phones in English education in Japan. Journal of Computer Assisted Learning, 21(3), 217-228. http: / / dx.doi.org/10.1111/j.13652729.2005.00129.x

To, P.-L., Liao, C. \& Lin, T.-H. (2007). Shopping motivations on Internet: A study based on utilitarian and hedonic value. Technovation, 27(12), 774-787. http: / / dx.doi.org/10.1016/j.technovation.2007.01.001

Tselios, N., Daskalakis, S. \& Papadopoulou, M (2011). Assessing the acceptance of a blended learning university course. Educational Technology E Society, 14(2), 224-235. http:/ / www.ifets.info/journals/14_2/19.pdf

Tung, F.-C., Chang, S.-C. \& Chou, C.-M. (2008). An extension of trust and TAM model with IDT in the adoption of the electronic logistics information system in HIS in the medical industry. International Journal of Medical Informatics, 77(5), 324-335. http:/ / dx.doi.org/10.1016/j.ijmedinf.2007.06.006

Turel, O., Serenko, A. \& Bontis, N. (2007). User acceptance of wireless short messaging services: Deconstructing perceived value. Information $\mathcal{E}$ Management, 44(1), 63-73. http: / / dx.doi.org/10.1016/j.im.2006.10.005

Venkatesh, V., Morris, M. G., Davis, G. B. \& Davis, F. D. (2003). User acceptance of information technology: Toward a unified view. MIS Quarterly, 27(3), 425-478. http: / / www.jstor.org/ stable/30036540

Wang, Y.-S., Lin, H.-H. \& Luarn, P. (2006). Predicting consumer intention to use mobile service. Information Systems Journal, 16(2), 157-179. http:/ / dx.doi.org/10.1111/j.13652575.2006.00213.x

Wang, Y.-S., Wu, M.-C., \& Wang, H.-Y. (2009). Investigating the determinants and age and gender differences in the acceptance of mobile learning. British Journal of Educational Technology, 40(1), 92-118. http: / / dx.doi.org/10.1111/j.1467-8535.2007.00809.x

Yoon, C. \& Kim, S. (2007). Convenience and TAM in a ubiquitous computing environment: The case of wireless LAN. Electronic Commerce Research E Applications, 6(1), 102-112. http: / / dx.doi.org/10.1016/j.elerap.2006.06.009

Authors: Dr Chi-Cheng Chang, Professor and Chairman
Department of Technology Application and Human Resource Development
National Taiwan Normal University, Taiwan. Email: samchang@ntnu.edu.tw
Chi-Fang Yan, National Taichung University of Science and Technology
Email: cfyan@ntit.edu.tw
Ms Ju-Shih Tseng
Department of Technology Application and Human Resource Development
National Taiwan Normal University, Taiwan. Email: jstseng@ntnu.edu.tw
Please cite as: Chang, C. C., Yan, C. F. \& Tseng, J. S. (2012). Perceived convenience in
an extended technology acceptance model: Mobile technology and English learning
for college students. Australasian Journal of Educational Technology, 28(5), 809-826.
http:// www.ascilite.org.au/ajet/ajet28/chang-cc.html

